Jurnal Pendidikan Bahasa dan Sastra Indonesia is licensed under A Creative Commons Attribution-Non Commercial 4.0 International License

\title{
Hal-Hal dan Alasan yang Diperjuangkan Para Tokoh pada Novel Ser! Randha Cocak Karya Suparto Brata
}

\author{
Murtiasih $^{1)}$, Wahyudi Joko Santoso ${ }^{2)}$ \\ 1. Universitas Negeri Semarang \\ Email: murtiasih7@gmail.com \\ 2. Universitas Negeri Semarang \\ Email:wahyudibsa@gmail.com
}

\begin{abstract}
Abstrak: Penelitian ini didasarkan pada pandangan bahwa sastra pada hakikatnya merupakan cerminan masyarakat. Jadi dalam penelitian ini, peneliti menggunakan pendekatan sosiologi sastra. Penelitian ini bertujuan untuk mendeskripsikan hal-hal yang diperjuangkan serta alasannya para tokoh pada novel Ser! Randha Cocak karya Suparto Brata. Metode yang digunakan adalah deskriptif analitik kualitatif. Sumber data dalam penelitian ini adalah novel Datanya adalah penggalan wacana yang diduga mengandung hal-hal yang diperjuangkan serta alasannya para tokoh pada novel Ser! Randha Cocak. Pengumpulan data dalam penelitian ini menggunakan teknik pustaka. Teknik analisis data dalam penelitian ini menggunakan metode pembacaan heuristik dan hermeneutik. Para tokoh Novel Ser! Randha Cocak karya Suparto Brata memperjuangkan cinta, kedudukan, warisan, dan nama baik. Adapun alasannya bahagia dengan pasangannya, hidup nyaman, menuntut yang menjadi haknya, dan mengembalikan nama baik.
\end{abstract}

Kata kunci : novel Ser!Randha Cocak, sosiologi; hal-hal yang diperjuangkan dan alasannya

\section{PENDAHULUAN}

Sastra lahir, tumbuh, dan hidup serta berkembang dalam masyarakat. Karya sastra diciptakan pengarang untuk dinikmati, dipahami, dan dimanfaatkan oleh masyarakat (Pradopo 1997:2). Sastra menampilkan gambaran kehidupan, dan kehidupan itu sendiri merupakan kenyataan sosial. Sastra lahir disebabkan dorongan dasar manusia untuk menaruh minat terhadap masalah manusia dan kemanusiaan juga menaruh minat terhadap dunia realitas yang berlangsung sepanjang hari dan sepanjang zaman. Senada dengan itu, Rusyana (1982:5) berpendapat bahwa sastra adalah hasil kegiatan kreatif manusia dalam mengungkapkan, penghayatannya dengan menggunakan bahasa. Pengungkapan realitas kehidupan tersebut menggunakan bahasa yang indah, sehingga dapat menyentuh emosi pembaca.

Novel Ser! Randha Cocak karya Suparto Brata diterbitkan tahun 2009 dipilih sebagai kajian dalam penelitian ini karena pertama karya sastra merupakan cerminan dari apa yang ada dalam masyarakat. Sehingga munculnya sebuah karya sastra yang diilhami oleh realita yang selalu memiliki makna yang mendalam yang ingin diungkapkan oleh pengarang. Menurut Damono dalam Faruk (2015:4) sastra merupakan cerminan masyarakat, sastra menampilkan gambaran kehidupan antar masyarakat dengan seseorang. Novel Ser! Randha Cocak merupakan novel fiktif namun novel karya Begawan Jawa tersebut memiliki realita dalan artian yang khusus yaitu dunia fiktif yang memberi kesan pada dunia atau merujuk pada dunia tertentu. Menurut Hawkes dalam Supriyanto, 2014:24) karya sastra (novel) dalam pikiran strukturalisme lebih merupakan susunan hubungan dari pada susunan benda-benda. Oleh Karena itu, kodrat tiap unsur dalam struktur itu tidak mempunyai makna dengan sendirinya, melainkan maknanya ditentukan oleh hubungan antarsemua unsur lain yang terkandung dalam struktur itu.

Novel Ser! Randha Cocak merupakan hasil karya Suparto Brata menghadirkan realita yang mengangkat permasalahan dengan menonjolkan sisi budaya, moral, spiritual, dan kemanusiaan untuk menyampaikan sebuah makna yang terkandung dalam novel. Kedua, karena novel Ser! Randha Cocak merupakan hasil karya Suparto Brata populer 
dikalangan masyarakat. Novel ini merupakan salah satu karya populer yang banyak dibaca oleh masyarakat khususnya masyarakat Jawa. Ketiga, novel Ser! Randha Cocak merupakan hasil karya Suparto Brata dipaparkan

Novel Ser! Randha Cocak meliputi 3 novel yaitu Ser! Ser! Plong, Mbok Randha saka Jogja, dan Ser! Ser! Plong menceritakan sang diploma yang bernama Patut Raharja tergesa-gesa pulang dari Amsterdam ke Jakarta karena mendapat $e$-mail dari ibundanya bahwa perempuan yang bernama Wangi Lestari telah ditemukan. Wangi Lestari merupakan partner menarinya sejak kecil. Hati Patut hanya untuk Wangi Lestari saja hingga menjadi seorang diplomat Patut masih tetap sendiri. Mbok Randha saka Jogja menceritakan perjuangan seorang janda di kota besar Surabaya. Cocak Nguntal Elo ini menceritakan tentang misteri atas meninggalnya tokoh Mawardi yang merupakan seorang direktur di Perusahaan real estate.

Sosok tokoh dalam karya sastra Jawa tampil dengan beragam budaya dan makna yang kaya akan suasana, seiring dengan maraknya issu jender semakin eksisnya kaum perempuan dalam berbagai bidang. Sementara itu pengantar sosiologi sastra sebagai suatu jenis pendekatan terhadap sastra yang memiliki paradigma dengan asumsi dan implikasi epistemologis yang berbeda dengan yang telah digariskan oleh teori sastra yang berdasarkan prinsip otonomi daerah.

Pemilihan para tokoh sebagai objek penelitian dengan alasan dari segi tokoh dalam cerita Ser! Randha Cocak pengarang menunjukkan kemodernan orang Jawa. Hal tersebut dibuktikan dengan cerita yang diangkat merupakan cerita yang menggambarkan tokoh-tokoh jawa yang bekerja dibidang formal, yakni studio dansa, diplomat, perkantoran pelayaran, perusahaan real estate. Pengarang juga menampilkan dialog para tokooh yang menggunakan bahasa asing. Bahasa Inggris dan Jepang. Tokoh-tokoh yang dipilih oleh pengarang dalam cerita merupakan manusia ideal jawa. Melalui tokoh-tokoh cerita tersebut pengarang menyampaikan berbagai permasalahan dalam keseluruhan rangkaian cerita.

Untuk mengungkap hal-hal dan alasan yang diperjuangkan para tokoh pada novel Ser! Randha Cocak karya Suparto Brata, maka penggalian dilakukan dengan menggunakan pendekatan struktural dan sosiologi sastra. Menurut Ratna (2014:93) strukturalisme sastra adalah pendekatan yang menekankan pada unsur-unsur didalam (segi intrinsik) karya sastra. Unsur-unsur karya sastra, terutama pada prosa di antaranya adalah tema peristiwa atau kejadian, latar, penokohan atau perwatakan, alur, dan sudut pandang. Satu konsep yang menjadi ciri khas teori struktural adalah adanya anggapan bahwa di dalam diri karya sastra merupakan suatu kesatuan yang bulat dengan unsurunsur pembangunannya yang saling berjalinan (Pradopo dalam Jabrohim, 2001:55).

Menurut Laurenson dan swingewood, terdapat tiga perpektif berkaitan dengan sosiologi sastra, yaitu: (1) penelitian yang memandang karya sastra sebagai dokumen sosial yang di dalamnya merupakan refleksi situasi pada masa sastra diciptakan, (2) penelitian yang mengungkapkan sastra sebagai cermin situasi social penulisnya, dan (3) penelitian yang menagkap sastra sebagai manifestasi peristiwa sejarag dan keadaan budaya (melalui Endraswara, 2003: 79).

Abrams (1999:289) mengatakan sosiologi sastra ditujukan pada tulisan-tulisan para kritikus dan ahli sejarah sastra yang utamanya diarahkan pada cara-cara pengarang dipengaruhi oleh status kelasnya, ideologi masyarakat, keadaan-keadaan ekonomi yang berhubungan dengan pekerjaannya, dan jenis pembaca yang dituju. Kesemuanya itu terangkum dalam aspek yang membangun sebuah cipta sastra, salah satu aspek yang membangun keutuhan sebuah cerita adalah menyangkut perwatakan tokoh-tokohnya.

Ada tiga hal yang harus diperhatikan dalam memposisikan sebuah karya sastra: (1) Sudut pandang yang menganggap bahwa sastra sama derajatnya dengan karya pendeta atau nabi. Dalam pandangan ini, tercakup juga pandangan bahwa sastra harus berfungsi sebagai pembaharu dan perombak. (2) Sudut pandang lain yang menganggap bahwa sastra bertugas sebagai penghibur belaka. Dalam hal ini gagasan-gagasan seni untuk seni misalnya, tidak ada bedanya dengan usaha untuk melariskan dagangan agar menjadi best seller. (3) Sudut pandang kompromistis seperti tergambar sastra harus mengajarkan dengan cara menghibur

(Damono

1979:4)

\section{METODE}

Penelitian ini menggunakan pendekatan teoretis dan pendekatan secara metodologis. Pendekatan penelitian yang digunakan dalam penelitian ini adalah pendekatan struktural dan pendekatan sosiologi sastra. Pendekatan sosiologi sastra didalamnya terdapat pendekatan objektif. Menurut Ratna (2014:73) pendekatan objektif merupakan pendekatan yang memusatkan perhatian semata-mata pada unsur-unsur, yang dikenal dengan analisis intrinsik. Pendekatan tersebut sesuai karena peneliti menganalisis tokoh cerita merupakan bagian dari unsur intrinsik suatu karya sastra. Pendekatan yang digunakan yakni pendekatan objektif karena berbicara masalah teks, tidak berbicara yang lain. Pendekatan objektif merupakan pendekatan yang bertumpu atas teks karya sastra itu sendiri. 
Bentuk penelitian yang digunakan dalam penelitian tentang kajian struktural dan sosiologi sastra dalam novel Ser! Randha Cocak karya Suparto Brata adalah penelitian deskriptif kualitatif. Bungin (2003:5) penelitian kualitatif membutuhkan kekuatan analisis yang lebih mendalam, terperinci namun meluas dan holistis, maka kekuatan akal adalah satu-satunya sumber kemampuan analisis dalam seluruh proses penelitian.

Ada tiga tahap yang digunakan untuk memecahkan masalah dalam penelitian ini, yakni penyediaan data, penganalisisan data, dan penyajian hasil analisis data (Sudaryanto 1993:5). Data merupakan suatu alat untuk memperjelas pikiran yang sesungguhnya merupakan sumber informasi yang diperoleh dari sumber data. Adapun sumber data adalah subjek kajian dari mana data diperoleh (Siswanto, 2005:63). Sumber data dalam penelitian ini adalah novel Ser! Randha Cocak karya Suparto Brata, Data pada penelitian ini berupa penggalanpenggalan wacana tertulis, dan perilaku yang diduga menunjukkan hal-hal yang diperjuangkan serta alasannya para tokoh pada novel Ser! Randha Cocak karta Suparto Brata.

Pengumpulan data dalam penelitian ini menggunakan teknik pustaka. Menurut Subroto (1992: 42), teknik pustaka adalah menggunakan sumber-sumber tertulis untuk memperoleh data. Selain menggunakan teknik pustaka, peneliti juga menggunakan teknik catat, penulis menggunakan teknik simak dan catat. Teknik pustaka adalah teknik yang menggunakan sumber-sumber tertulis untuk memperoleh data.

Teknik analisis data dalam penelitian ini menggunakan metode pembacaan heuristik dan hermeneutik. Metode pembacaan heuristik merupakan cara kerja yang dilakukan oleh pembaca dengan mengintepretasikan teks sastra secara referensial lewat tanda-tanda linguistik. Pembacaan heuristik juga dapat dilakukan secara struktural (Pradopo dalam Sangidu 2004:19). Kerja heuristik menghasilkan pemahaman makna secara harfiah, makna tersurat, aktual meaning (Nurgiyantoro 1991:33). Langkah selanjutnya adalah metode pembacaan hermeneutik. Menurut Pradopo (2007:135), hemeneutika merupakan pemahaman karya sastra yang berdasarkan sistem tingkat kedua yang berkaitan dengan penafsiran di luar teks sastra.

\section{HASIL DAN PEMBAHASAN}

Para tokoh Novel Ser! Randha Cocak karya Suparto Brata memperjuangkan cinta, kedudukan, warisan, dan nama baik. Selain menjabarkan hal yang diperjuangkan para tokoh pada novel tersebut juga akan dijabarkan beberapa alasan hal-hal tersebut diperjuangkan.

\section{Cinta}

Tokoh-tokoh yang memperjuangkan cinta adalah Patut, Wangi Lestari, Wungu, Dororini, dan Martiyas. Patut memperjuangkan cintanya pada Wangi Lestari. Ia segera pulang setelah mendapat pos elektronik ibunya yang mengabarkan Wangi telah ditemukan.

Patut segera meminta ijin atasannya dan meninggalkan Negara Belanda untuk menemui Wangi Lestari. Patut yang hidup dibayang-bayangi kenangan masa kecil membuat hatinya beku terhadap perempuan, tetapi setelah bertemu Wangi Lestari Patut memancing-mancing kenangan masa kecilnya. Akan tetapi Wangi Lestari sama sekali tidak ingat peristiwa tersebut.

"Nanging, kenangan mangsa kliwat kuwi sing marakake aku ora noleh marang wong wadon liya. Mung marang wong wadon Wangi sing daktresnani jaman mbiyen!" (SSP:42).

"Tapi, kenangan masa lalu itu yang membuat aku tidak menoleh perempuan lain. Hanya perempuan Wangi yang kucintai jaman dulu!" (SSP:42).

Sebenarnya Patut merasa jatuh cinta pada perempuan yang mengaku Yuni Shara sejak pertama kali bertemu. Akan tetapi dari pihak perempuan meskipun tetarik dengan Patut berusaha jual mahal. Yuni Shara tidak menolak untuk menjalin hubungan lebih lanjut. Tapi melihat jadwal yang dipaparkan begitu padat membuat Patut putus asa karena tidak ada waktu untuknya.

Harapan Patut kembali tumbuh ketika tanpa sengaja Patut bertemu lagi dengan Yuni Shara diacara full time. Hatinya semakin terpesona ketika Yuni Shara mendemostrasikan dansa bersama Linuwih. Hal itu dapat dilukiskan pada penggalan wacana berikut ini.

"Amrik Ngambarwangi mesem ngujiwat. Nrima lamarane Patut ngajak dansah mung karo kedhepe mripat, lan manggute janggut. Cukup nggawe kiprahe gentleman from Amsterdam kedandapan, gurawalan nampani tangan aluse, ngrangkul bangkekane, ditarik alon menyang papan pagebyangan" (SSP:59). "Amrik Ngambarwangi tersenyum menggoda. Menerima permintaan Patut yang mengajak dansa dengan mata berkedip, dan anggukan. Cukup membuat satria dari Amsterdam tidak menentu, salah tingkah menerima tangan halusnya, merangkul pinggang, ditarik pelan menuju tempat menari "(SSP:59). 
Selanjutnya tokoh yang memperjuangkan cinta adalah Wungu. Wungu datang ke Jakarta untuk menyamar menjadi Wangi Lestari. Wungu datang ke bandara bermaksud untuk menemui Patut secara diam-diam. Akan tetapi sampai waktu yang telah dijadwalkan, pesawat yang ditumpangi Patut belum datang juga. Ketika sedang mencari-cari sosok Patut, Wungu bertabrakan dengan laki-laki gondrong dan terjatuh. Lelaki gondrong tersebut langsung menolong Wungu dan mereka berkenalan. Wungu melihat penampilan laki-laki tersebut langsung terpesona apalagi setelah mengenal laki-laki tersebut ternyata salah satu pemilik studio dancer. Ia langsung mengejar laki-laki tersebut untuk belajar menari mengingat Patut seorang diploma yang pandai menari apalagi dansa. Maka Wungu harus dapat menyesuaikan agar penyamarannya lebih menyakinkan.

Hati Wungu semakin tidak menentu ketika masuk ruangan ternyata Patut langsung terpesona dengan pasangan menari Linuwih. Wungu bahagia setelah Linuwih mengumumkan bahwa yang dirinya yang dicintai.

Dororini, perempuan cantik sekretaris Darbe Sampurna pemimpin perusahaan besar Segara Bawera. Dia merasa dengan kecantikannya siapapun akan tertarik. Akan tetapi sebaliknya karyawan di kantor tidak ada yang menarik hatinya. Ia ingin menarik hati Darbe Direktur di kantornya. Tetapi kelihatannya Darbe bukan sosok laki-laki yang mudah tergoda dengan perempuan cantik. Dororini semakin sakit hatinya karena Darbe lebih memilih Janda dari Jogja yang bernama Citraresmi daripada dirinya.

Dororini sudah merasa kalah bersaing dengan Citraresmi untuk menarik hati Darbe Sampurna. Dororini mengadu kepada Martiyas apa yang telah ia lihat terkait kedekatan Darbe dengan pegawai baru. Tetapi Martiyas tidak mempercayai apa yang diceritakan Dororini. Ketika dalam puncak kejengkelan melihat sepak terjang Citraresmi, Dororini teringat $\mathrm{Bu}$ Marjanji. Niat hatinya sudah bulat untuk melaporkan Darbe Sampurna. Dororini tidak mau tahu akibat yang akan ditimbulkan karena ulahnya.

Sebagai pengobat luka hatinya, Ia mendekati adik direktur yaitu Martiyas. Hanya Martiyas yang sering mengajaknya keluar untuk sekadar makan. Dororini menutupi jadi dirinya demi dapat menarik simpati Martiyas. Dororini mengira Martiyas jatuh cinta padanya karena seringnya diajak makan bersama. Tidak hanya itu saja ketika ada acara ulang tahun ibunya Martiyas, Ia diundang kerumahnya. Bu Marjanji menyetujui hubungan Martiyas dengannya.

"Hiss! Aja. Wis randha, lo kuwi! Ora mung randha teles, randha gatel! Rak ya mesake Dororini! Adhikmu ki wis jaka tuwa, lo Jung kan wis nemu Dororini, aku cocog. Kok, saiki digodha mbok randha saka Jogja! Kuwi mengko Dororini rak priye? Ki mau Dororini lapor nyenthenyenthe, genah yen nesu banget! Gage Njung, adhikmu slametna! Ditokake wae kuwi saka kantor. Aja nampa pegawe randha gatel (MRSJ:148).

"Hiss! Jangan, Sudah janda, lo itu! Tidak hanya randha teles, janda nakal! Apa tidak kasihan Dororini! Adikmu sudah perjaka tua, lo Jung kan sudah menenukan Dororini, aku sudah cocok, sekarang digoda janda dari Jogja! Itu nanti Dororini bagaiman? Tadi dororini lapor dengan amarah, jelas itu kelihatan sangat marah! Segera Njung, adikmu diselamatkan! Dikeluarkan dari kantor. Jangan menerima janda nakal (MRSJ:148).

Usaha Dororini untuk merebut hati Martiyas dengan cara mendekati Bu Marjanji. Meskipun $\mathrm{Bu}$ Marjanji menjodohkan Martiyas dengan Dororini tetapi Martiyas hatinya lebih terpikat pada Citraresmi. Dororini dalam memperjuangkan cintanya sudah tidak ada harapan lagi ketika keluarga besar Martiyas mengumumkan perempuan yang dipilih Martiyas tidak lain adalah Citraresmi.

$\mathrm{Bu}$ Marjanji setelah dibujuk Martinjung dan Martiyas akhirnya luluh hatinya. Beliau merestui hubungan Martiyas dan Citraresmi. Ketika selesai wisata Keluarga besar Martiyas mengumumkan pertunangan Martiyas dengan Citraresmi. Dororini kecewa tidak mengira kalau cintanya akan berakhir menyakitkan.

Tokoh yang juga memperjuangkan cinta adalah Martiyas. Martiyas merupakan direktur anom bagian forwading atau EMKL. Martiyas terpesona dengan perempuan yang mengiringi tamu dari Jepang. Bu Marjanji melarang keras putranya menjalin hubungan dengan perempuan yang bernama Citraresmi. Bu Marjanji menyuruh Martiyas untuk menjauhi perempuan tersebut. Martiyas diminta segera memutuskan hubungan dan menjauhi janda dari Jogja. Ibunya lebih cocok dengan Dororini karena Dororini masih perawan dan cantik. Sedangkan perempuan yang baru diajak makan adalah seorang janda dari Jogja.

Pengakuan Citraresmi sama seperti yang diceritakan ibunya. Sehingga semakin membuat hatinya bimbang meskipun jelas hatinya sudah kasmaran dengan Citraresmi. Ketika dalam kebimbangan. Martiyas mendapat telpon dari kakaknya yang mendukung keputusan adiknya. Martiyas semakin gemas dengan kakaknya karena digoda habis. Hal itu dapat terlihat pada penggalan wacana berikut ini. 
"Lo, kowe sing bakal nglakoni, yo kowe sing kudu milih, menimbang. Aku wis weruh bocahe, wong wingi aku ya melu nemoni tamu saka Jepang. Kuwi pegawe pilihane Mas Darbe, ora mung dipilih ayune nanging uga bobot-bibit-bebete. Kowe dhewe rak ya wis menangi tandang tanduke wingi? Aku jumurung wae, apa karepmu" (MRSJ:149)

"Lo, kamu yang akan menjalani, ya kamu yang harus memilih, menimbang. Aku sudah tahu orangnya, kemarin aku juga ikut menemui tamu dari Jepang. Itu pegawai pilihannya Mas Darbe, tidak hanya dipilih karena cantik tetapi bobot-bibit-bebetnya. Kamu sendiri kemarin kan sudah melihat sepak terjangnya? Aku mendukung saja , apa yang menjadi keinginanmu (MRSJ:149).

Setelah mendapat penjelasan dan dukungan dari kakaknya, Martiyas semakin yakin dengan pilihannya. Meskipun sudah tahu bahwa Citraresmi sudah janda. Sekarang yang menjadi penghalang cintanya hanya ibunya. Martiyas harus berpikir bagaimana cara mendekatkan Citraresmi dengan ibunya. Kebetulan para karyawan mengadakan wisata. Martiyas mengajak keluarganya untuk ikut acara wisata. Akhirnya keluarga besar Martiyas bergabung ikut wisata dengan karyawan.

Martiyas meminta kakaknya untuk mendekatkan Citraresmi dengan ibunya. Bu Marjanji hatinya luluh setelah Martinjung menjelaskan panjang lebar jati diri Citraresmi. Akhirnya pada kegiatan penutupan keluarga besar Darbe Sampurna mengumumkan pertunangan antara Martiyas dan Citraresmi dihadapan para karyawan. Martinjung yang mengumumkan perempuan yang telah merebut hati adiknya. Hal itu dapat terlihat pada penggalan wacana berikut ini.

"Yas, arekmu kirimna mrene! kowe wis dhemen tenan ta? Arep daktakon-takoni dhisik. Randha ora preduli, anggere kowe dhemen tenan, aku setuju.

"Aja diladaki, lo, anggere!"

"Ora. Malah yen arekmu kuwi setuju bubaran piknik iki mengko diumumke pisan tunanganmu karo ..., sapa Njung, jenenge? (MRSJ:164).

"Yas, orangnya antarkan kesini! Kamu sudah benar-benar suka ta? mau ibu tanyatanya dulu. Janda tidak peduli. Asal kamu benar-benar suka, ibu setuju.

"Asal jangan digalaki, ya!"
"Tidak. Malah kalau orangnya itu setuju setelah piknik ini nanti diumumkan sekalian tunanganmu dengan ..., siapa Njung, namanya? (MRSJ:164).

Para tokoh memperjuangkan cinta untuk hidup bahagia dengan pasangan yang dicintainya.

\section{Kedudukan}

Tokoh yang memperjuangkan kedudukan adalah Dororini dan Surahana. Dororini meninggalkan desanya pergi ke Surabaya untuk melamar pekerjaan. Ia melamar pekerjaan sebagai sekretaris dan mengaku masih sendiri. Dororini mengaku masih perawan didaftar lamaran pekerjaan dengan harapan peluang untuk diterima lebih besar. Awalnya ia merasa menjadi sekretaris sudah aman. Akan tetapi setelah kedatangan Citraresmi kedudukan Dororini di perusahaan merasa terganggu.

Dororini pergi ke Surabaya melamar sebagai sekretaris. Awalnya mengira menjadi sekretaris sudah aman dan dapat berkembang pesat apalagi $\mathrm{Bu}$ Marjanji tertarik untuk menjadikan dirinya sebagai menantu. Harapan dan kenyamanan hilang ketika kedatangan Citraresmi yang berani secara terangterangan mengatakan Dororini bekerja tidak sesuai yang ditempati karena tidak memiliki ijazah sekretaris. Tidak hanya itu, selama ia menjadi sekretaris belum pernah diajak makan oleh direkturnya apa lagi diajak jalan-jalan.

Hatinya Dororini hancur ketika harapan untuk menjadi istri Martiyas gagal. Dororini gagal memperjuangkan kedudukannya sebagai sekretaris maupun pasangan salah satu pemilik saham perusahan Segera Bawera. Selanjutnya selain Dororini yang memperjuangkan kedudukan ada tokoh lain adalah Surahana. Surahana yang memiliki kecerdasan pas-pasan bekerja di Perusahaan Pak Mawardi. Pak Mawardi memiliki putri yang cantik tetapi manja dan malas untuk berpikir. Surahana berusaha mendekati putri Pak Mawardi dengan harapan mencapai kedudukan yang diincarnya.

Ketika mengetahui Pak Mawardi meninggal di pesawat pada saat akan melakukan perjalanan bisnis, Surahana mendekati Sekar agar hubungannya segera diresmikan. Kabar kematian Pak Mawardi membuat Sekar tidak stabil. Keadaan yang tidak stabil tersebut dimanfaatkan oleh Surahana. Ia memengaruhi pikiran Sekar.

"La, saiki kowe kabeh ngreti lan dadi seksi yen anggon kita nikahan iki ora ana peksan. Sing paling penting, kowe kabeh kudu ngreti yen nikahan iki nuruti amanate Pak Mawardi Jalin. Ya.?" (CNE:194).

"La, sekarang kaliyan semua tahu dan menjadi saksi kalau pernikahan kita ini tidak ada paksaan. yang terpenting, kalian 
semua harus tahu pernikahan ini menuruti amanat pak Mawardi Jalin. Ya?"(CNE:194).

Surahana sudah tidak sabar ingin segera memulai rapat. Ketika meminta pada salah satu peserta rapat untuk memulai rapat. Rapat ditunda karena masih menunggu satu peserta yang belum rapat. Setelah orang yang ditunggu-tunggu datang yaitu Wening Perbani. Rapat segera dimulai. Tetapi selama rapat hati Surahana terganggu karena peserta yang bernama Wening selalu menyela rapatnya terus.

Selain itu, karena Surahana takut Sekar dijodohkan dengan Wisnu. Surahana berusaha menyingkirkan Wisnu dengan membayar orang lain. Orang yang disuruh salah sasaran yang kena bukan Wisnu melainkan Pak Mawardi.

Harapan Surahana untuk menguasai harta kekayaan Pak Mawardi dengan menikahi Sekar siasia. Sekar bukanlah ahli waris satu-satunya Pak Mawardi. Sekar hanya anak dari istrinya atau anak tiri Pak Mawardi. Surahana menyesal menikah dengan Sekar Sekar hanya memiliki KTP, SIM, STNK Honda Jazz. Selain itu uang di ATM sebesar lima puluh juta. Tetapi uang tersebut digunakan untuk kebutuhan pemakaman pak Mawardi. Selain untuk biaya pemakaman, uang tersebut digunakan Surahana sesuka hatinya. Segala sesuatu diselesaikan dengan uang. Surahana ibarat Cocak Nguntal Elo. Surahana mengejar kedudukan sampai jatuh bangun dan melakukan segala cara sampaisampai berurusan dengan polisi.

"Si Cocak ora kuwat nguntal omah Pasar Jumat saisine! Dhisike rak butarepan, dikira Pak Wisnu arep dipek mantu dening Pak Mawardi, terus pak Wisnu diakali arep disingkirake, diperjaya wae. Senajan rajapati salah sasaran, sajak malah kebenaran.(CNE:259).

"Si Cocak tidak kuwat menelan rumah Pasar Jumat seisinya! Dulunya kan cemburu, dikira Pak Wisnu akan dijadikan menantu Pak Mawardi, terus Pak Wisnu diakali akan disingkirkan, dibunuh saja. Meskipun pembunuhan salah sasaran, malah kebetulan (CNE:259).

\section{Ahli Waris}

Tokoh yang memperjuangkan ahli waris adalah Wening Perbani. Wening mengetahui suaminya meninggal dari ibunya. Bu Jodhi yang mendapat telpon dari Wisnu. Wening janji sama Wisnu akan datang ke Jakarta pada saat rapat pleno.

Wening menanyakan Surahana siapa yang memberi wewenang untuk memimpin menjadi direktur. Karena untuk menjadi direktur tidak gampang. Banyak syarat yang harus dipenuhi. Surahana hatinya semakin panas karena diragukan statusnya sebagai direktur

Mendengar permintaan Wening, peserta rapat jadi gaduh dan meragukan apakah jenazah yang dikirim tersebut bukan jenazah Pak Mawardi. Wening juga meminta bukti KTP dan Kartu Keluarga yang menjelaskan keluarga Pak Mawardi. Surahana semakin terpojok karena kenyataannya Ia tidak memiliki bukti yang diminta oleh Wening. Wening menjelaskan bahwa jenazah yang dikirim ke Jakarta benar. Permintaan Wening tentang KTP dan KK tidak dapat dipenuhi oleh Surahana karena memang Surahana tidak menemukan bukti-bukti yang memperkuat statusnya.

Surahana berpikir kalau menikahi Sekar akan dapat menguasai semua warisan Pak Mawardi. Kenyataannya hanya Wening yang dapat menunjukkan bukti KTP dan KK yang dibutuhkan. KTP dan KK menujukkan bahwa Wening satusatunya ahli waris dari Pak Mawardi. Selain menunjukkan KTP, Wening juga menujukkan Surat nikahnya dengan Pak Mawardi. Hal itu dapat dilihat pada penggalan wacana (80) berikut ini.

"Lan iki surat kawinku! Surat nikahku karo Pak Mawardi Jalin, rong taun kepungkur, ana ing Surabaya. Kanthi mangkono, dudu Sekar sapa kuwi mau sing nampa warisane Pak Mawardi Jalin, nanging aku, Wening Prabani.!" (CNE:235).

"Dan ini surat nikahku! Surat nikahku dengan Pak Mawardi Jalin, dua tahun yang lalu, ada di Surabaya. Dengan begitu, bukan Sekar siapa itu tadi yang meneri warisannya Pak Mawardi Jalin, tetapi aku, wening Prabani!" (CNE:235).

Wening mendapat haknya sebagai ahli waris satu-satunya. Setelah melalui perdebatan panjang. Wening tetap menyelesaikan studi di Amerika. Urusan Perusahaan PT Griya Kedhaton Alit dipasrahkan pada Wisnu Nugraha. Hal itu dapat dilihat pada penggalan wacana berikut ini. Wening membuka rahasia yang selama ini dirahasiakan yaitu tentang dirinya sebagai istri sah Pak Mawardi. Wening menunjukkan bukti-bukti bahwa dirinya merupakan istri sahnya.

\section{Nama Baik}

Tokoh yang memperjuangkan nama Baik adalah Wisnu. Wisnu mengabari keluarga Pak Mawardi Jalin bahwa Pak Mawardi telah meninggal dalam pesawat. Wisnu dituduh oleh Surahana telah memanfaatkan pengiriman jenazah Pak Mawardi. Surahana menyangka kalau Wisnu sengaja menunda pengiriman jenazah. Meskipun Wisnu merupakan 
pekerja baru, tapi keberadaannya telah menyita hati Pak Mawardi.

Wisnu selalu dipuji akan kejeniusannya. Hal itu membuat Surahana semakin membenci Wisnu. Surahana ketakutan kalau Wisnu akan merusak tujuannya. Sampai-sampai Sekar ditanya tentang hubungannya dengan Wisnu.

Surahana selalu marah-marah jika bertemu Wisnu. Wisnu sakit hati karena dikatakan mengancam. Wisnu tergerak hatinya, siang itu sebelum jenazah diberangkatkan Surahana menikah dengan Sekar. Wisnu meminta kejelasan pemimpin langsung, Sandihakim tentang pernikahan Surahana dan Sekar, terkait dengan surat keterangan dokter dan KTP. Wisnu masih curiga. Wisnu juga bertanya pada pembantu Pak Mawardi yang bertanya Sembada. Meskipun sudah dijelaskan secara jelas, Wisnu masih penasaran. Kemudian menanyakan pada petugas kantor makam. Jawabannya sama. Wisnu kembali dari pemakaman harus menerima kenyataan karena semua yang diragukan ternyata sesuai yang dibutuhkan. Akan tetapi hatinya masih saja penasaran bagaimanapun juga pernikahan di depan jenazah itu hal yang aneh. Wisnu pulang ke rumahnya. Sesampainya di rumah, ia tidak dapat istirahat dengan tenang. Wisnu masih kepikiran tentang meninggalnya Pak Mawardi dan semua ubarampe pengiriman dan pemakaman jenazah. Tiba-tiba Wisnu teringat KTP yang difotokopi di kantor polisi dan dokter, berbeda. Hal itu dapat terlihat pada penggalan wacana berikut ini.

Greg! Wisnu cekekal njenggirat tangi. KTP sing difotokopi ing kantor polisi lan dhokter, beda karo sing difaks, Wisnu lali blas prekara KTP biru kuwi. Lan ora nglegewa blas prekara warnane KTP. Pokok njupuke saka dhompete Pak Mawardi., ya mesthi kuwi KTP-ne Pak Mawardi. (CNE:238).

Greg! Wisnu segera terbangun. KTP yang difotokopi di kantor polisi dan dokter, berbeda dengan yang difaks, Wisnu lupa sama sekali masalah KTP biru tersebut. Dan tidak menyangka sama sekali masalah warnanya KTP. Pokoknya mengambil dari dompetnya Pak Mawardi, ya pasti itu KTP-nya Pak Mawardi. (CNE:238)

Wisnu tidak percaya setelah terhubung dengan alamat di Surabaya, Pak Mawardi memiliki keluarga. Ia berkeinginan pergi ke Surabaya untuk membuka misteri, Wisnu pergi ke Kantor untuk ijin dulu karena kantor tetap berjalan seperti biasa.

Sesampainya di Surabaya, ia disambut $\mathrm{Bu}$ Jodhi mertua dari Pak Mawardi. Wisnu berkenalan dengan Wening istri dari Pak Mawardi yang kuliah di Amerika. Wening cerita panjang lebar terkait hubungannya dengan Pak Mawardi. Hari Rabu, perusahaan Kedhaton Alit mengadakan rapat yang dipimpin Surahana.

"Kenapa Wisnu melu cawe-cawe prekara rapat iki?. Kenapa sing kudu diendel omongane Wisnu? Wisnu kuwi rak mung pegawe andhahane Pak Sandihakim? ujare Surahana kadidene pangarsa rapat dina kuwi, ketara ora sabar enggal mbukak rapat". (CNE:225)

"Kenapa Wisnu ikut campur tangan masalah rapat ini? Kenapa yang harus diturutoi kata Wisnu? Wisnu itu kan hanya pegawainya Pak Sandihakim? Kata Surahana sebagai pemimpin rapat hari itu, kelihatan tidak sabar ingin segera membuka rapat". (CNE:225)

Selesai rapat. Surahana kalah bukti, ing rapat selanjutnya hanya menjadi wakil direktur, bukan ahli waris Pak Mawardi. Rapat dipimpin Wening Perbani. Wisnu diangkat sebagai pengganti Wening Perbani selama menyelesaikan studinya di Amerika.

Kesimpulan dari data-data di atas, demi nama baiknya Wisnu yang merasa dituduh membunuh Pak Mawardi. Wisnu berusaha mencari kebenaran tentang meninggalnya Pak Mawardi.

\section{SIMPULAN DAN SARAN}

Pada novel Ser! Randha Cocak karya Suparto Brata, yang diperjuangkan para tokoh meliputi cinta, kedudukan, warisan, dan nama baik. Alasan mereka, untuk hidup bahagia dengan pasangannya, hidup lebih nyaman, menuntut yang menjadi haknya, dan mengembalian nama baiknya.

\section{DAFTAR PUSTAKA}

Abrams, M. H. (1999). A Glossary of Literary Terms. Earl McPeek:USA.

Bungin, Burhan. (2003). Analisis Data Penelitian Kualitatif. Jakarta: Rajawali.

Damono, Supardi Djoko. (1979). Pedoman Penelitian Sosiologi Sastra. Jakarta: Pusat Bahasa Pendidikan Nasional.

Damono, Supardi Djoko. (2015). Sosiologi Sastra: Sebuah Pengantar. Jakarta: Pusat Pembinaan dan Perkembangan Bahasa Departemen Pendidikan dan Kebudayaan. 
Endraswara, Suwardi. (2003). Metodologi Penelitian Sastra: Epistemologi, Model, Teori, dan Aplikasi. Yogyakarta: CAPS

Faruk. (2015). Pengantar Sosiologi Sastra dari Strukturalisme Genetik Sampai Post Modernisasi. Yogyakarta: Pustaka Pelajar.

Jabrohim. (2001). Metodologi Penelitian Sastra. Yogyakarta: Graha Widya.

Nurgiyantoro, Burhan. (1991). Dasar-dasar Kajian Fiksi (Sebuah Teori Pendekatan Fiksi. Yogyakarta: Gadjah Mada University Press.

Pradopo, Rachmat Djoko. (1997). Prinsip-prinsip Karya Sastra (Teori dan Penerapannya). Yogyakarta. Gadjah Mada University Press.

Ratna, Nyoman Kutha. (2014). Teori, Metode, dan Teknik Penelitian Sastra. Yogyakarta: Pustaka Pelajar.

Rusyana, Yus. (1982). Metode Pengajaran Sastra. Bandung : CV Diponegoro.

Sangidu. (2004). Penelitian Sastra: Pendekatan, Teori, Metode, Teknik, dan Kiat. Yogyakarta: Unit Penerbitan Sastra Asia Barat.

Siswanto. (2014). Metode Penelitian Sastra (Analisis Struktur Puisi). Yogyakarta: Pustaka Pelajar.

Subroto, Edi. (1992). Pengantar Metode Penelitian Linguistik Struktural. Surakarta: Sebelas Maret University press.

Sudaryanto. (1993). Memahami Cerita Rekaan. Yogyakarta: Pustaka Jaya.

Sumaryono, E. (1999). Hermeutik: Sebuah Metode Filsafat.Yogyakarta: Kanisius.

Supriyanto, Teguh.(2014). Kajian Stilistika dalam Prosa. Yogyakarta: Elmatera. 